\title{
A preliminary study of trace metals and porphyrins in excreta of Gentoo penguins (Pygoscelis papua) at two locations of the Antarctic Peninsula\#
}

\author{
Estudio preliminar de metales traza y porfirinas en heces de pingüinos \\ Papua (Pygoscelis papua) en dos localidades de la península Antártica \\ J Celis ${ }^{\mathrm{a}^{*}}$, S Jara ${ }^{\mathrm{b}}$, D González-Acuña ${ }^{\mathrm{a}}$, R Barra ${ }^{\mathrm{b}}$, W Espejo ${ }^{\mathrm{a}}$ \\ aDepartamento de Ciencias Pecuarias, Facultad de Ciencias Veterinarias, Universidad de Concepción, Chillán, Chile. \\ bUnidad de Sistemas Acuáticos, Centro de Ciencias Ambientales EULA-Chile, Universidad de Concepción, Concepción, Chile.
}

\section{RESUMEN}

\begin{abstract}
Aunque las concentraciones de la mayoría de los elementos químicos en la Antártica son bajas en comparación con otras áreas del planeta, éstas se han ido incrementando con el tiempo debido al gran crecimiento de la población y desarrollo industrial de los países del Hemisferio Sur, lo cual podría estar afectando a especies vulnerables como los pingüinos. Se determinaron las concentraciones (peso seco) de arsénico (As), cadmio (Cd), mercurio $(\mathrm{Hg})$ y plomo $(\mathrm{Pb})$ y porfirinas (copro-, uro- y proto-) en heces de colonias de pingüinos Papua (Pygoscelis papua), colectadas en dos lugares de la península Antártica (O'Higgins y Videla). Se encontraron mayores $(\mathrm{P}<0,05)$ niveles de $\mathrm{Hg}\left(7,55 \pm 1,28 \mu \mathrm{g} \mathrm{g}^{-1}\right)$ en las heces de colonias de pingüinos en O'Higgins, mientras que las colonias de pingüinos en Videla exhibieron mayores concentraciones de Cd $\left(1,68 \pm 0,71 \mu \mathrm{g} \mathrm{g} \mathrm{g}^{-1}\right)$. Los pingüinos Papua de O'Higgins mostraron mayores $(\mathrm{P}<0,05)$ niveles de copro- $(1,81 \pm 0,61 \mathrm{nmol} \mathrm{g}-1)$, uro- $\left(1,74 \pm 0,72 \mathrm{nmol} \mathrm{g}^{-1}\right)$ y protoporfirinas $(1,24 \pm 0,46 \mathrm{nmol}$ $\left.\mathrm{g}^{-1}\right)$, en directa relación con los mayores niveles de $\mathrm{Hg}$ y Pb medidos. Esto podría implicar que algunas colonias de pingüinos Papua de la península Antártica están propensas a desarrollar algunos efectos bioquímicos asociados a contaminación por metales traza. Estos resultados preliminares levantan inquietantes interrogantes acerca de la contaminación de origen antropogénico que estaría afectando áreas tan remotas como la Antártica.
\end{abstract}

Key words: heavy metals, excrement, bio-monitoring, seabirds, Antarctic, polar region.

Palabras clave: metales pesados, excremento, bio-monitoreo, aves marinas, Antártica, región polar.

\section{INTRODUCTION}

Heavy metal contamination is wide spread globally as a result of mining and other industrial processes. Human activities such as oil spills, sewage, hazardous wastes, pesticides, mining, smelting or forest fires could contribute to increase $\mathrm{Hg}$, As and $\mathrm{Cd}$ levels, whereas electrical devices, mining or explosives could increase $\mathrm{Pb}$ levels in marine ecosystems (Boersma 2008). However, heavy metals are difficult to estimate as pollutants because these chemicals occur naturally in the environment (Ancora et al 2002). In any case, there are evidences showing that remaining pristine regions of the planet are being affected, and environmental contamination researches on these ecosystems attracted great interest from the scientific community (Smichowski et al 2006).

Antarctica is a remote, polar region surrounded by oceans, and seems far away from industrial and other high impact anthropogenic activities. However, recent studies

\footnotetext{
Accepted: 14.06.2012.
}

\# Financiado por Instituto Antártico Chileno (project INACH T 18-09 and T 27-10) and Comisión Chilena de Investigación Científica y Tecnológica (project FONDECYT 1110719).

* Casilla 537, Chillán, Chile; jcelis@udec.cl have shown pollution affecting Antarctic fauna, which could be linked to a raising tourist activity and research activities or some local environmental accidents (Lohan et al 2001, Sanchez-Hernandez 2000, Negri et al 2006).

Because seabirds are top predators, long-lived, often feed on a long distance from land and exhibit different trophic levels, they are sentinels of environmental changes in ecosystems (Boersma 2008). Heavy metals are toxic for mammals and birds, and can cause severe damage to kidneys, liver and the central nervous system (Szefer $e t$ al 1993, Kim et al 1998, Horai et al 2007).

A useful technique to determine the risk of chemical exposure in wildlife and humans is the use porphyrins profile alterations as a marker of biochemical effects (De Matteis and Lim 1994). Porphyrins comprise a large, diverse and universal group of organic compounds. They are a group of metabolites that participate in the biosynthesis of haemoglobin and cytochroms. They are produced and accumulate in trace amounts in erythropoietic tissues such as liver and kidneys and are excreted via urine or faeces (Lim 1991). Porphyrins are capable of binding metals and can be detected in different biological materials, even at very low concentrations (De Matteis and Lim 1994). This characteristic makes it possible for porphyrins to be used as biomarkers for measuring the level of exposure to heavy metals such as $\mathrm{Pb}, \mathrm{Hg}$ and As in seabirds and 
mammals (Casini et al 2003). Also, some environmental contaminants such as heavy metals, can interfere with heme biosynthesis causing alterations in the level of porphyrins that are accumulated or excreted (Casini et al 2001). The resulting oxide by-products as copro-, uro- and protoporphyrins are not toxic at normal levels, but when accumulated in excess can affect liver and bony marrow (Lim 1991). There is evidence showing a direct correlation between metal pollution and accumulation of porphyrins in liver and excreta (Leonzio et al 1996).

Even though concentrations of most chemical elements in Antarctic ecosystems appear to be very low, a continuous level of contamination due to population's growth and industrial development in countries of the Southern Hemisphere could be affecting some endemic species with unique ecophysiological characteristics, like penguins (Bargagli 2008). Biomaterials such as plants, lichens, mosses, algae, tissues and organs have been usually used as environmental bioindicators. However, they can be difficult to obtain due to strict regulations for wildlife protection, or just because living organisms are generally difficult to monitor in an ecosystem (Yin et al 2008). For that reason, the aim of this research was to determine the concentrations of some trace metals and porphyrins in excrements from colonies of Gentoo penguins (Pygoscelis рариа) at two locations of the Antarctic Peninsula.

\section{MATERIAL AND METHODS}

Fresh samples of excreta from Gentoo penguin colonies were collected during February of 2011 at two locations of the Antarctic Peninsula (figure 1). Twenty excreta samples $(4 \mathrm{~g})$ were collected from Gentoo penguin colonies breeding at Videla $\left(63^{\circ} 28^{\prime} \mathrm{S}, 56^{\circ} 17^{\prime} \mathrm{W}\right)$ and other twenty samples from Gentoo penguin colonies breeding at O'Higgins $\left(63^{\circ} 19^{\prime} \mathrm{S}, 57^{\circ} 53^{\prime} \mathrm{W}\right)$. Fresh excrements were produced by penguins in the past couple of days, and are generally brown with white spots (Yin et al 2008). Both stations are usually occupied by a small crew of maintenance personnel and are currently visited by scientific staff and tourists from September to March, particularly O'Higgins, located $150 \mathrm{~km}$ from King George Island.

Samples were put into polyethylene bags, stored at $-4{ }^{\circ} \mathrm{C}$ and freeze-dried before analysis. Samples were washed with distilled water, dried at room temperature and then ground and screened ( 24 mesh $\mathrm{dm}^{-2}$ ). Then samples were digested with nitric acid $\mathrm{HNO}_{3}$ (Ancora et al 2002). The levels of elements in the samples were determined by atomic fluorescency for $\mathrm{Hg}$, whereas atomic absorption spectrometry (for As) with graphite furnace (for $\mathrm{Cd}$ and $\mathrm{Pb}$ ) was used. In order to ensure quality control a certified reference material, human hair, was used as an internal standard in a proportion of $10 \%$ each batch of samples.

Porphyrins were determined as described by Lockwood et al (1985). Briefly, $1 \mathrm{ml}$ hydrochloric $(\mathrm{HCl}) 5 \mathrm{~N}$ solution was placed in a graduated centrifuge tube containing 100 $\mathrm{mg}$ excreta and vortex-mixed. Diethyl ether $(3 \mathrm{ml})$ was added and mixed to obtain an emulsion; then $3 \mathrm{ml}$ water were added and the solution was mixed again and then centrifuged at $700 \mathrm{~g}$ for $10 \mathrm{~min}$. The supernatant was decanted and the precipitant containing the porphyrins was exposed to fluorimetric analysis (Casini et al 2001).

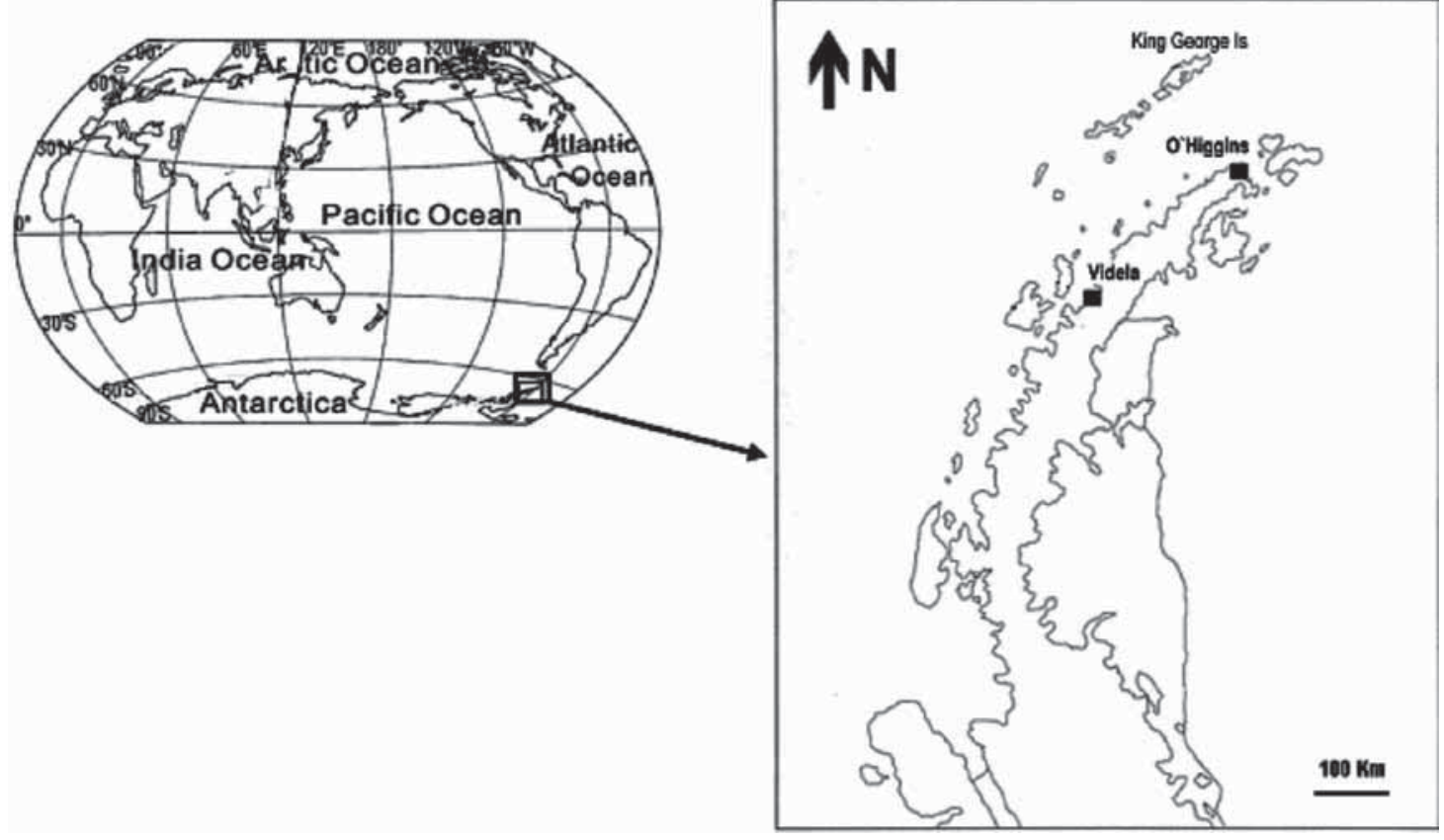

Figure 1. Location of sampling sites at the Antarctic Peninsula. Ubicación de los sitios de muestreos en la península Antártica. 
Means and standard deviations were calculated for all the groups using descriptive statistics. Differences among colonies in metals and porphyrins concentrations in Videla and O'Higgins were analysed by using one-way ANOVAs, although a nonparametric test (Mann-Whitney) was used when the assumptions of normality and homocedasticity were not met (Jerez et al 2011). Concentrations were log-transformed to meet the normality assumptions of the statistical analyses, which were conducted in Statistica software (Statsoft). Pearson's correlation coefficients were calculated for trace metals and porphyrins to study the existence of any relations among data collected. The level of significance was set at $\mathrm{P} \leq 0.05$. The detected levels are presented as mean \pm standard deviation in $\mu \mathrm{g}$ $\mathrm{g}^{-1}$ dry weight.

\section{RESULTS AND DISCUSSION}

Figure 2 shows the heavy metal concentration in excrements of Gentoo penguins collected at both locations. The Hg concentration in the excrements of Gentoo penguins collected at $\mathrm{O}^{\prime}$ Higgins station was significantly 7 times higher $\left(7.55 \pm 1.28 \mathrm{\mu g} \mathrm{g}^{-1}\right)$ than that of penguins at Videla station and $\mathrm{Pb}$ levels were twice higher $\left(0.75 \pm 0.84 \mu \mathrm{g} \mathrm{g}^{-1}\right)$ than that of penguins at Videla station. The $\mathrm{Cd}(1.68 \pm 0.71$ $\left.\mu \mathrm{g} \mathrm{g}^{-1}\right)$ and As $\left(0.50 \pm 0.40 \mu \mathrm{g} \mathrm{g}^{-1}\right)$ concentrations measured at Videla were twice higher than those of penguins at O'Higgins location. The following relationship among trace elements was observed in penguins at Videla: $\mathrm{Cd}$ $>\mathrm{Hg}>\mathrm{As}>\mathrm{Pb}$, compared to penguins at O'Higgins where it was $\mathrm{Hg}>\mathrm{Cd}>\mathrm{Pb}>\mathrm{As}$.

The Hg levels we detected were 70 times higher than those reported in excrements of Gentoo penguins and 40 times higher than those of Chinstrap penguins (P. antarctica) at King George Island (Yin et al 2008). Moreover, $\mathrm{Hg}$ levels were 30 times higher than those reported in Adélie penguins ( $P$. adeliae) at Terra Nova Bay, Ross Sea (Ancora et al 2002), a remote area highly influenced by volcanic emissions (Bargagli et al 1998). As a result, penguin colonies in O'Higgins Station have been exposed to higher levels of $\mathrm{Hg}$.

$\mathrm{The} \mathrm{Pb}$ levels we found were $25 \%$ lower than those reported in excrements of Gentoo penguins and 57\% lower than those in Chinstrap penguins at King George Island (Yin et al 2008). We detected As concentrations one order of magnitude higher than those reported by Jerez et al (2011) in soft tissues of Adélie penguin chicks from King George Island, and two orders of magnitude of those levels measured by Smichowski et al (2006). Our results for As and $\mathrm{Cd}$ are higher than those of Jerez et al (2011) who reported levels under $0.20 \mu \mathrm{g} \mathrm{g}^{-1}$ for As and $0.1 \mu \mathrm{g} \mathrm{g}^{-1}$ for $\mathrm{Cd}$ in feathers of Adélie penguins and Chinstrap penguins, respectively. The

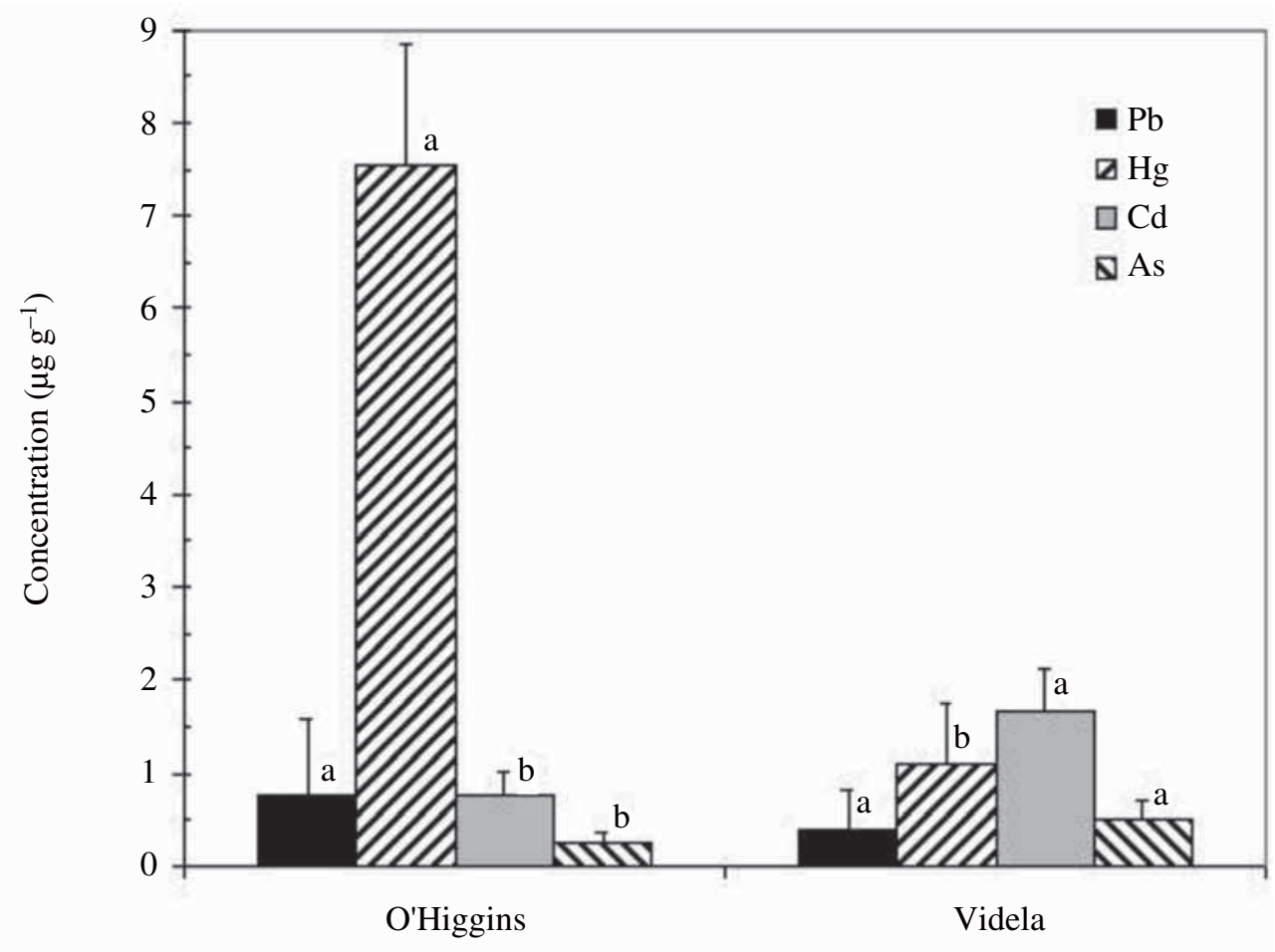

Figure 2. Mean concentrations of trace metals from samples of excrements of Gentoo penguin colonies measured at O'Higgins and Videla, Antarctic Peninsula. Colonies with the same letter for a given element are not significantly different $(\mathrm{P}<0.05)$.

Concentraciones medias de metales traza en muestras de excrementos de colonias de pingüinos Papua medidas en O’Higgins y Videla, península Antártica. Colonias con la misma letra para un elemento dado no son significativamente diferentes $(\mathrm{P}<0,05)$. 
Cd levels we found are $70 \%$ lower than those reported by Ancora et al (2002) in excreta of Adélie penguins breeding at Edmonson Point (Terra Nova bay, Antarctica). It may indicate that the excrements of penguins are more useful for monitoring traces of heavy metals than feathers, as also noted by Jerez et al (2011), a point that should be more deeply investigated.

Various human activities are known to be $\mathrm{Hg}$ and $\mathrm{Pb}$ sources, such as charcoal combustion, waste incineration, sewage disposal, paint or oil spills (Bargagli 2008, Santos et al 2005). In our case, $\mathrm{Hg}$ and $\mathrm{Pb}$ detected at $\mathrm{O}$ 'Higgins location seem to be related to a higher concentration of human activities that exists in the Antarctic Peninsula, where shipping, boating, and loading and unloading of fuel and goods are more concentrated, when compared to other Antarctic areas. In fact, there is a small airport at King George Island, where there is heavy traffic of vessels, planes, and helicopters to transport tourists, scientists and support personal (Tin et al 2009). Furthermore, people from all over the world must stop over there just before they reach the Antarctic Peninsula. There is some evidence of $\mathrm{Pb}$ contamination caused by Antarctic scientific stations, as previously reported by Boutron and Patterson (1987). Additionally, some evidence indicates there is a global metal transport resulting in the deposition of airborne metals to the marine ecosystem (Yin et al 2008).
Significantly twice $\mathrm{Cd}$ and As levels were detected in Gentoo penguins at Videla, a location more distant from King George Island than O'Higgins, seem strongly related to local volcanism in the area under study (Deheyn et al 2005, Jerez et al 2011), even though anthropogenic activities can not be neglected. $\mathrm{Cd}$ is one of the most biotoxic elements; it binds strongly to metallothioneins, proteins in the membranes of cell organelles, in the kidney of marine vertebrates, and levels increase with age in some marine mammals (Smichowski et al 2006).

Although regional volcanic emissions are a possible natural source of $\mathrm{Hg}$ in Antarctica (Bargagli et al 1998), the higher $\mathrm{Hg}$ levels found at O'Higgins when compared to Videla (a more remote location) suggest a possible human source. The traffic of vehicles by sea and air around the coast of O'Higgins may be an important factor for $\mathrm{Hg}$ bioaccumulation.

Figure 3 shows the levels of porphyrins found in excreta from penguins at O'Higgins and Videla locations. Higher levels $(\mathrm{P}<0.05)$ of proto- $\left(1.24 \pm 0.46 \mathrm{nmol} \mathrm{g}^{-1}\right)$,

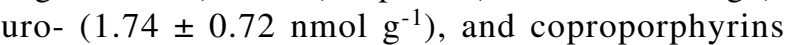
$\left(1.81 \pm 0.62 \mathrm{nmol} \mathrm{g}^{-1}\right)$ corresponded at O'Higgins, where coincidently we found higher $\mathrm{Hg}$ and $\mathrm{Pb}$ concentrations in the excrements. As previously noted, O'Higgins constitutes an area with currently heavier anthropogenic activity than Videla. Despite the lack of studies on porphyrins

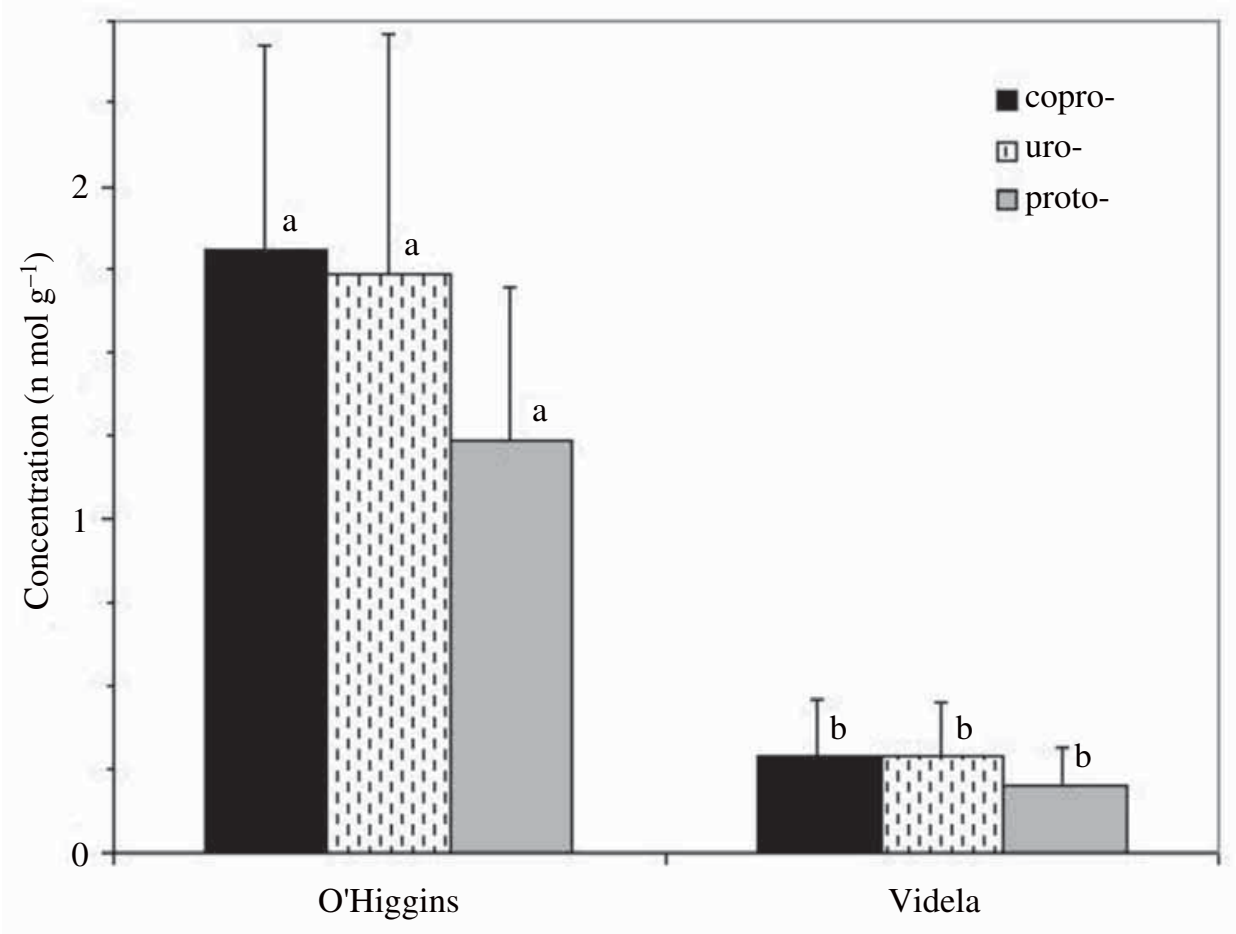

Figure 3. Mean concentrations of porphyrins from samples of excrements of Gentoo penguin colonies measured at O'Higgins and Videla, Antarctic Peninsula. Colonies with the same letter for a given porphyrin are not significantly different $(\mathrm{P}<0.05)$.

Concentraciones medias de porfirinas en muestras de excrementos de colonias de pingüinos Papua medidas en O’Higgins y Videla, península Antártica. Colonias con la misma letra para una porfirina dada no son significativamente diferentes $\mathrm{P}<0,05)$. 
Table 1. Pearson correlation among trace metals ( $\mathrm{As}, \mathrm{Cd}, \mathrm{Hg}, \mathrm{Pb}$ ) and porphyrins (copro-, uro-, proto-) in excrements of $\mathrm{Gentoo}$ penguins (*significant at $\mathrm{P} \leq 0.05,2$-tailed, $\mathrm{n}=40$ ).

Correlación Pearson entre metales traza (As, $\mathrm{Cd}, \mathrm{Hg}, \mathrm{Pb}$ ) y porfirinas (copro-, uro-, proto-) en excrementos de pingüinos Papua (*significativo a $\mathrm{P} \leq 0,05,2$ colas, $n=40$ ).

\begin{tabular}{llllcccc}
\hline & $\mathrm{As}$ & $\mathrm{Cd}$ & $\mathrm{Hg}$ & $\mathrm{Pb}$ & Copro- & Uro- & Proto- \\
\hline $\mathrm{As}$ & 1 & 0.303 & -0.249 & -0.288 & -0.198 & -0.201 & -0.219 \\
$\mathrm{Cd}$ & 0.303 & 1 & -0.238 & -0.130 & -0.219 & -0.223 & -0.246 \\
$\mathrm{Hg}$ & -0.249 & -0.238 & 1 & 0.286 & $0.707^{*}$ & $0.709^{*}$ & $0.731^{*}$ \\
$\mathrm{~Pb}$ & -0.288 & -0.130 & 0.286 & 1 & $0.736^{*}$ & $0.742^{*}$ & $0.729^{*}$ \\
Copro- & -0.198 & -0.219 & $0.707^{*}$ & $0.736^{*}$ & 1 & $0.995^{*}$ & $0.999^{*}$ \\
Uro- & -0.201 & -0.223 & $0.709^{*}$ & $0.742^{*}$ & $0.995^{*}$ & 1 & $0.997^{*}$ \\
Proto- & -0.219 & -0.246 & $0.731^{*}$ & $0.729^{*}$ & $0.999^{*}$ & $0.997^{*}$ & 1 \\
\hline
\end{tabular}

in penguin excrements to which we could compare our results, a Pearson analysis showed that higher levels of copro-, uro- and protoporphyrins in penguins are directly related to higher levels of $\mathrm{Hg}$ and $\mathrm{Pb}$ (table 1). The $\mathrm{Hg}$ and $\mathrm{Pb}$ concentrations, as well as $\mathrm{Cd}$ and $\mathrm{As}$, show a positive relationship that may indicate that the source of pollution could be the same or closely related for each pair of metals.

Although metal concentrations appear to be lower than $10 \mu \mathrm{g} \mathrm{g}^{-1}$ (dry weight) as described in faeces from other bird's species from non-contaminated areas (Beyer et al 1997, Mateo et al 2006, Martinez-Haro et al 2010), our results suggest that adverse physiological effects in Gentoo penguins could be triggering even at low exposure levels.

The results indicate that $\mathrm{Hg}$ and $\mathrm{Pb}$ contamination can be assessed by using porphyrins as a nondestructive biomarker in penguins. It is consistent with findings of Leonzio et al (1996), who showed that birds treated with $\mathrm{Hg}$ led to accumulation of porphyrins in liver and excreta. Also, a local study suggested the use of porphyrins in excreta of sea birds as a biomarker of exposure of contaminants (Casini et al 2001). $\mathrm{Hg}$ and $\mathrm{Pb}$ concentrate porphyrins in the kidney and pancreas, affecting their functions (Lim 1991, Casini et al 2003). Gentoo penguins prey mainly on coastal fishes and krill (Euphausia superba) of the Antarctic Ocean (Berón et al 2002). Trace metals detected in penguins are strongly related to high metal levels found in the Antarctic krill (Barbante et al 2000) and usually found in fish (Szefer et al 1993, Beltcheva et al 2011). This may explain why Gentoo penguins are reflecting metal pollution.

These preliminary findings reveal that Gentoo penguins living around O'Higgins are potentially likely to suffer some illness for $\mathrm{Hg}$ and $\mathrm{Pb}$ pollution. Our results suggest that Gentoo penguins are a sentinel for monitoring porphyrins in excreta, as previously observed in other birds, such as gulls and cormorants (Casini et al 2001), and also geese (Mateo et al 2006). However, further research in the area is extremely needed to examine potential local sources of contamination.

\section{SUMMARY}

Even though concentrations of most chemical elements in Antarctic ecosystems are very low as compared to other world's areas, their increasing time trends, as a consequence of the strong population growth and industrial development in countries of the Southern Hemisphere, could be affecting some vulnerable endemic species such as penguins. Concentrations (dry weight) of arsenic (As), cadmium (Cd), mercury $(\mathrm{Hg})$ and lead $(\mathrm{Pb})$ and porphyrins (copro-, uro- and proto-) were determined in feces of Gentoo penguins (Pygoscelis papua), collected at two locations of the Antarctic Peninsula (O'Higgins and Videla). We found higher $(\mathrm{p}<0.05)$ levels of $\mathrm{Hg}$ in excreta of penguin colonies at O'Higgins ( $7.55 \pm 1.28 \mu \mathrm{g}$ g- 1 ), whereas penguins at Videla showed the highest concentrations of $\mathrm{Cd}(1.68 \pm 0.71 \mu \mathrm{g} \mathrm{g}-1)$. Gentoo penguins from O'Higgins site showed higher levels of copro- $(1.81 \pm 0.61 \mathrm{nmol} \mathrm{g}-1)$, uro- $(1.74 \pm 0.72 \mathrm{nmol} \mathrm{g}-1)$ and protoporphyrins $(1.24 \pm 0.46 \mathrm{nmol} \mathrm{g}-1)$, directly related to higher levels of $\mathrm{Hg}$ and $\mathrm{Pb}$ measured. These findings imply that some Gentoo penguin colonies of the Antarctic Peninsula are likely to develop some biochemical effects through trace metal contamination at some level. These preliminary results raise concerns about anthropogenic pollutants in Antarctica.

\section{REFERENCES}

Ancora S, V Volpi, S Olmastroni, S Focardi, C Leonzio. 2002. Assumption and elimination of trace elements in Adélie penguins from Antarctica: a preliminary study. Marine Environ Res 54, 341-344.

Barbante C, G Cozzi, G Capodagli, P Cescon. 2000. Trace element determination in a candidate reference material (Antarctic krill) by ICP-sector field MS. J Anal At Spectrom 15, 377-382.

Bargagli R, F Monaci, JC Sanchez-Hernandez, D Cateni. 1998. Biomagnification of mercury in an Antarctic marine coastal food web. Mar Ecol Prog Ser 1, 169, 65-76.

Bargagli R. 2008. Environmental contamination in Antarctic ecosystems. Sci Total Environ 400, 212-226.

Beltcheva M, R Metcheva, V Peneva, M Marinova, Y Yankov, V Chikova. 2011. Heavy metals in Antarctic notothenioid fish from South Bay, Livingston Island, South Shetlands (Antarctica). Biol Trace Elem Res 141, 150-158.

Berón MP, NR Coria, M Favero. 2020. Monitoreo de la dieta postreproductiva del pingüino papua (Pygoscelis papua) en Isla Laurie (Orcadas del Sur, Antártida): período 1997-1999. Ornitol Neotrop $13,413-422$.

Beyer, NW, LJ Blus, CJ Henny, DA Audet. 1997. The role of sediment ingestion in exposing wood ducks to lead. Ecotoxicol 6, 181-186.

Boersma PD. 2008. Penguins as marine sentinels. Bioscience 58, 597-607. 
Boutron C, C Patterson. 1987. Relative levels of natural and anthropogenic lead in recent Antarctic snow. J Geophys Res 29, 8454-8464.

Casini S, M Fossi, J Gavilan, R Barra, O Parra, C Leonzio, S Focardi. 2001. Porphyrin levels in excreta of sea birds of the Chilean coasts as nondestructive biomarker of exposure to environmental pollutants. Arch Environ Contam Toxicol 41, 65-72.

Casini S, M Fossi, C Leonzio, A Renzoni. 2003. Review: porphyrins as biomarkers for hazard assessment of bird populations: destructive and non-destructive use. Ecotoxicology 12, 297-305.

Deheyn D, P Gendreau, R Baldwin, M Latz. 2005. Evidence for enhanced bioavailability of trace elements in the marine ecosystem of Deception Island, a volcano in Antarctica. Marine Environ Res 60, 1-33.

De Matteis F, CK Lim. 1994. Porphyrins as nondestructive indicators of exposure to environmental pollutants. In: Fossi MC, Leonzio C (eds). Nondestructive Biomarkers in Vertebrates. Lewis Publishers, Boca Raton, Florida, USA, Pp 93-128.

Horai S, I Watanabe, H Takada, Y Iwamizu, T Hayashi, S Tanabe, K Kuno. 2007. Trace element accumulations in 13 avian species collected from the Kanto area, Japan. Sci Total Environ 373, 512-525.

Jerez S, M Motas, M Palacios, F Valera, J Cuervo, A Barbosa. 2011. Concentration of trace elements in feathers of three Antarctic penguins: geographical and interspecific differences. Environ Pollut 159, 2412-2419.

Kim EY, R Goto, S Tanabe, H Tanaka, R Tatsukawa. 1998. Distribution of 14 elements in tissues and organs of Oceanic seabirds. Arch Environ Contam Toxicol 35, 638-645.

Leonzio C, MC Fossi, S Casini. 1996. Porphyrins as biomarkers of methylmercury and PCBs exposure in experimental quail. Bull Environ Contam Toxicol 56, 244-250.

Lim CK. 1991. Porphyrins. In: Hanai T (ed). Liquid chromatography in biomedical analysis. Elsevier, Amsterdam, The Netherlands, Pp 209-229.

Lockwood WH, V Poulus, E Rossi, D Curnow. 1985. Rapid procedure for fecal porphyrin assay. Clin Chem 31, 1163-1167.
Lohan MC, PJ Statham, L Peck. 2001. Trace metals in the Antarctic softshelled clam Laternula elliptica: implications for metal pollution from Antarctic research stations. Polar Biol 24, 808-817.

Martinez-Haro, M, M Taggart, R Mateo. 2010. Pb-Al relationships in waterfowl feces discriminate between sources of $\mathrm{Pb}$ exposure. Environ Pollut 158, 2485-2489.

Mateo R, M Taggart, A Green, C Cristofol, A Ramis, A Lefranc, J Figuerola, A Meharg. 2006. Altered porphyrin excretion and histopathology of greylag geese (Anser anser) exposed to soil contaminated with lead and arsenic in the Guadalquivir marshes, southwestern Spain. Environ Toxicol Chem 25, 203-212.

Negri A, K Burns, S Boyle, D Brinkman, N Webster. 2006. Contamination in sediments, bivalves and sponges of McMurdo Sound, Antarctica. Environ Pollut 143, 456-467.

Sanchez-Hernandez JC. 2000. Trace element contamination in Antarctic ecosystems. Rev Environ Contam Toxicol 166, 83-127.

Santos I, E Silva-Filho, C Schaefer, M Albuquerque-Filho, L Campos. 2005. Heavy metal contamination in coastal sediments and soils near the Brazilian Antarctic Station, King George Island. Marine Pollut Bull 50, 185-194.

Smichowski P, C Vodopivez, R Muñoz-Olivas, A Gutierrez. 2006. Monitoring trace elements in selected organs of Antarctic penguin (Pygoscelis adeliae) by plasma-based techniques. Microchem J $82,1-7$.

Szefer P, W Czarnowski, J Pempkowiak, E Holm. 1993. Mercury and major essential elements in seals, penguins, and other representative fauna of the Antarctica. Arch Environ Contam Toxicol 25, 422-427.

Tin T, Z Fleming, K Hughes, D Ainley, P Convey, C Moreno, S Pfeiffer, J Scott, I Snape. 2009. Impacts of local human activities on the Antarctic environment. Antarct Sci 21, 3-33.

Yin X, L Xia, L Sun, H Luo, Y Wang. 2008. Animal excrement: a potential biomonitor of heavy metal contamination in the marine environment. Sci Total Environ 399, 179-185. 